\title{
A hypothesis to explain ganglion cell death caused by vascular insults at the optic nerve head: possible implication for the treatment of glaucoma
}

\author{
Neville N Osborne, José Melena, Glyn Chidlow, John P M Wood
}

Some apparent characteristics of ganglion cell death in glaucoma

Glaucoma is a progressive optic neuropathy with characteristic optic disc changes and associated visual field defects. ${ }^{12}$ The pattern and progression of visual field loss due to ganglion cell death varies between glaucoma patients suggesting that there is some variability in the magnitude of the insult responsible for the cell loss. Ganglion cell death with a spatial and temporal distribution typical of "glaucoma" can be experimentally induced in animals..$^{3-5}$ One way to try and mimic glaucoma in experimental animals is to raise the intraocular pressure (IOP). ${ }^{3-6}$ It is clear from such studies that ganglion cells do not all die at the same time. ${ }^{4-8}$ Furthermore, the rate of deterioration of ganglion cells is proportional to the magnitude of the insult. ${ }^{9}$ The reason for the initiation of ganglion cell death in glaucoma is unknown, but a number of explanatory theories have been proposed with the vasogenic theory perhaps the most widely accepted hypothesis. $^{2}{ }^{10-12}$

Oligaemic/hypoxic insult to the optic nerve head leads to ganglion cell death in glaucoma

Raised IOP is not the sole factor responsible for glaucomatous retinal damage but an important one of a number that have been implicated (Fig 1). ${ }^{12-17}$ Only $10 \%$ of patients

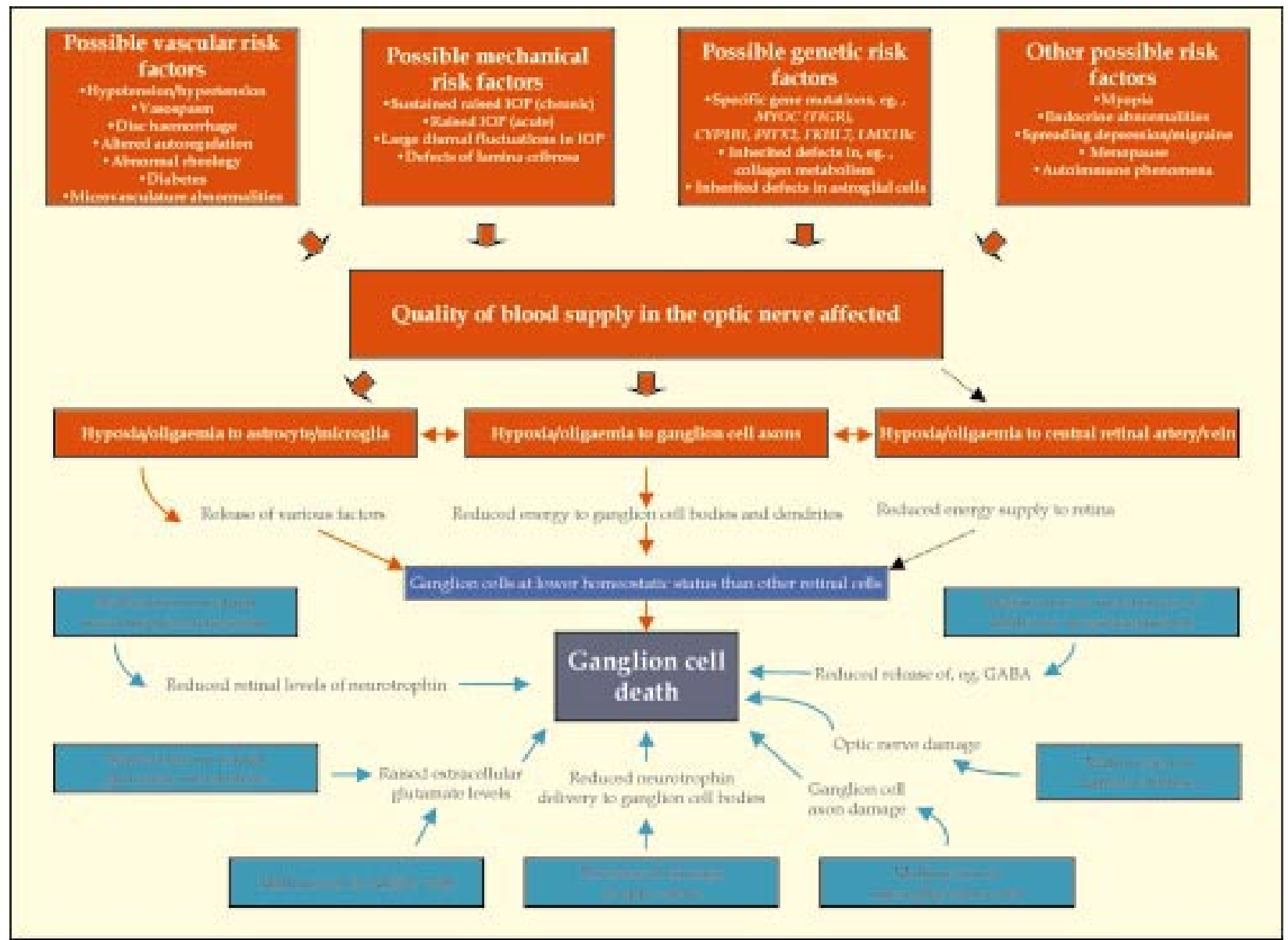

Figure 1 Possible causes of ganglion cell death in glaucoma. It is suggested that activation of sufficient risk factors causes the quality of blood supply in the optic nerve head to be affected. As a result, the nutritional supply to the optic nerve head is slowly compromised (oligaemialhypoxia) particularly affecting astrocytes, microglia, and ganglion cell axons. Even the central retinal artery/vein may become slightly affected. Such insults eventually lead to the death of ganglion cells as depicted and detailed in Figures 2 and 3. One may also envisage other modes of stimulating ganglion cell death in glaucoma (lighter blue boxes) where the vascular system does not have a direct role. Some of these possibilities may also be linked to certain risk factors, but these are not indicated. 
with increased IOP ( $\geqslant 22 \mathrm{~mm} \mathrm{Hg}$ ) have glaucoma and between one third and one half of patients with glaucoma initially do not have elevated IOP. ${ }^{18}{ }^{19}$ Furthermore, as many as one sixth of patients with glaucomatous damage do not appear to have elevated IOP. ${ }^{1}$ It is therefore clear that raised IOP is not synonymous with having glaucoma. ${ }^{12021}$ Nevertheless, high IOP is arguably the most important risk factor (see Fig 1), and it is clearly associated with ganglion cell death in glaucoma patients.

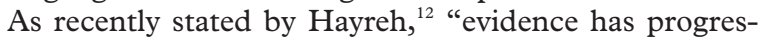
sively accumulated to suggest that vascular insufficiency at the optic nerve head plays an important role in the pathogenesis of glaucomatous optic neuropathy and that glaucomatous optic neuropathy is a multifactorial disease." A strong case has been made out to support the view that an alteration in the quality of blood supply in the optic nerve head can lead to glaucoma. ${ }^{12} 17$ 22-32 The main blood supply to the optic nerve head is from the posterior ciliary artery via the peripapillary choroid and short posterior ciliary arteries or the circle of Zinn-Haller. ${ }^{26}$ It is the quality of the blood supply from these vessels that may be particularly affected, rather than the blood flow in the central retinal artery. An alteration in the quality of blood supply in the optic nerve head capillaries could be indirectly triggered to a greater or lesser extent by increased IOP (due to collapse of the lamina cribrosa?), abnormal blood pressure, altered rheological characteristics of the blood, local vasospasm, possibly haemorrhage, autoregulatory defects, or changes in the physiological and/or physical characteristics of the blood vessels in question. Should this occur then the tissues in the optic nerve head might suffer oligaemic and/or hypoxic insults because the local oxygen supply would be altered. It is of interest to note that in experimental studies a decrease in ocular (particularly uveal) blood flow occurs when the IOP is elevated. ${ }^{33} 34$ There is, however, no good evidence to show that elevated pressure directly influences blood flow in the region of the lamina cribrosa although it has been proposed that blood flow regulatory mechanisms may be faulty in this region in glaucoma. ${ }^{35-37}$ It seems reasonable, therefore, to hypothesise that an alteration in the quality of the blood supply in the microcirculation of the optic nerve head caused by direct and indirect actions of a combination of risk factors leads to an oligaemic/hypoxic insult. This then contributes to ganglion cell death (with the initial insult being at the axonal level at the optic nerve head) in certain glaucoma patients. ${ }^{1722} 2538$ Unfortunately no satisfactory method exists to measure the blood dynamics in the optic nerve head of glaucoma patients to demonstrate whether oligaemia/hypoxia occurs.

\section{A hypothesis to explain how differential ganglion cell death may occur}

Both visual field $\operatorname{loss}^{39} 40$ and neuroretinal rim loss ${ }^{41}$ appear to follow typical patterns in glaucoma, which would imply that certain ganglion cells are more susceptible than others. Also, a preferential loss of ganglion cells in the peripheral retina seems to occur in experimental glaucoma both in monkeys ${ }^{42}$ and rats. ${ }^{7}$ It would appear, therefore, that a differential rate of death of ganglion cells occurs. One explanation is that a greater rotation or disruption of the cribrosal beams at the periphery of the optic disc accounts for a periphery to centre progression of visual field loss in glaucoma. However, some evidence exists to suggest that axons from peripheral and central areas of the retina may randomly pass through peripheral or central parts of the optic nerve (see Morgan ${ }^{11}$ ), which argues against a close correlation between the pattern of visual field loss in glaucoma and the anatomical position of ganglion cell axons at the optic nerve head. We previously proposed $^{43}$ that the specific pattern of ganglion cell death in glaucoma (differential ganglion cell death) could be influenced by the repertoire of inhibitory and excitatory receptors associated with each ganglion cell. In the present review, we hypothesise that both the axonal injury at the optic nerve and the repertoire of inhibitory and excitatory receptors of each ganglion cell have a major role in determining the cell's fate in glaucomatous neuropathy.

Should oligaemia/hypoxia occur in the optic nerve head how could it lead to a similar but not identical pattern of ganglion cell loss in glaucoma patients? One such proposal is outlined in Figure 2. Components that are likely to be affected include ganglion cell axons, astrocytes, microglia, and the lamina cribrosa. ${ }^{44-47}$ A sustained (or intermittent) oligaemic/hypoxic insult to such components before loss of ganglion cell function may contribute to the "cupping" associated with glaucoma. It is of importance to note that glaucomatous visual field abnormalities have been reported to precede structural changes of the optic nerve head and nerve fibre layer. ${ }^{48-52}$ Structural changes at the optic nerve head may therefore be apparent before total loss of ganglion cell function, supporting the opinion that the initial insult in glaucoma occurs at the optic nerve head and that the death of the ganglion cell soma is not the cause for the "cupping." An increase in the intracellular calcium concentration in ganglion cell axons as a result of oligaemia/hypoxia may trigger disruption of axonal transport and cytoskeletal breakdown as demonstrated in isolated optic nerves under hypoxic conditions. ${ }^{53}$ Sustained or intermittent insults to groups of astrocytes in the optic nerve head region could also cause them to become "reactive," change shape, possibly swell, ${ }^{54}$ and even die. Astrocytes in the lamina cribrosa and prelaminar region of the optic nerve head provide structural and cellular support and participate in forming the extracellular matrix. ${ }^{11}{ }^{47}$ After an oligaemic/ischaemic insult at the optic nerve head, astrocytes may become "reactive" eliciting a variety of possible effects. These may include disrupting axoplasmic transport, initiating changes in cribrosal physiology and biochemistry, alterations in matrix modelling and the release of potential toxins (nitric oxide, tumour necrosis factor $\alpha$, transforming growth factor $\beta$, glutamate); all contributing to the characteristic form of glaucomatous optic neuropathy. ${ }^{47-60}$ Moreover, D-serine may be released from stressed astrocytes to potentiate the agonistic effect of glutamate at NMDA receptors, ${ }^{61}$ so exacerbating ganglion cell injury. It should be noted that optic disc "cupping" has been reported in other conditions leading to optic nerve head ischaemia, such as compressive optic neuropathy, anterior ischaemic neuropathy, and Leber's optic neuropathy, ${ }^{62-65}$ although it may not be a consistent feature. A recent population study revealed that "cupping" of the optic nerve head is found in $92 \%$ of eyes with arteritic anterior ischaemic optic neuropathy and in $2 \%$ of eyes with non-arteritic anterior ischaemic optic neuropathy. ${ }^{63}$ The reasons for the low incidence of "cupping" in non-arteritic anterior ischaemic optic neuropathy are unknown, but it has been proposed by Hayreh ${ }^{66}$ that the ischaemic process may not be as marked and massive as in arteritic anterior ischaemic optic neuropathy. It may well be that similar alterations in the quality of the blood supply to certain regions of the optic nerve head develop both in glaucoma (in a chronic, slowly progressive way) and arteritic anterior ischaemic optic neuropathy (in an acute, rapidly progressive way) leading to a similar, although not identical, "cupping" of the optic disc.

Astrocytes are abundant in the optic nerve head as well as throughout the remainder of the retina and have the 


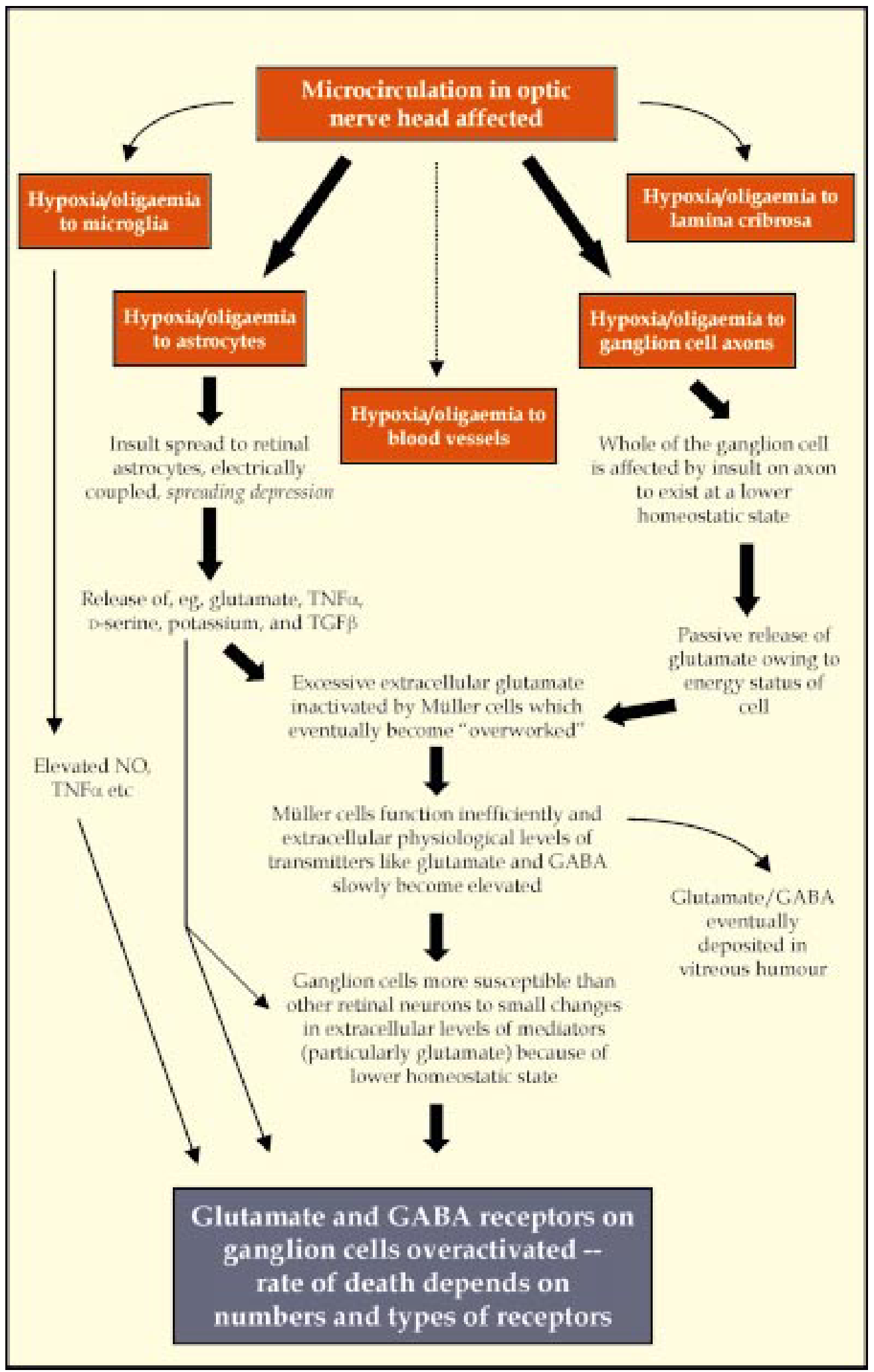

Figure 2 A hypothesis to explain ganglion cell death in glaucoma. Various components in the optic nerve head may be affected by oligaemia/hypoxia as a result of an alteration in the microcirculation (see Fig 1). While the ganglion cell axon may be affected in the initial stages of the insult, the whole of the cell will eventually suffer (exist at a lower homeostatic state) with glutamate particularly being "non-physiologically" released into the extracellular space (Fig 3). Astrocytes and microglial cells are also likely to release a variety of substances into the extracellular space after an undefined duration of insult. Some of these substances may have "protective" properties while others will have adverse effects on neurons. Moreover, increased levels of glutamate in the extracellular space are potentially toxic to many retinal cells. Müller cells will as a consequence become particularly active in an attempt to maintain physiological levels of extracellular neurotransmitters. However, the excessive demands placed on Müller cells will eventually lead to them becoming inefficient. This will result in a slow but gradual rise in the level of glutamate and other neurotransmitters (for example, GABA) in the extracellular space. The ganglion cells, being at a lower homeostatic status than other retinal cell types will potentially, therefore, be more susceptible to this extracellular rise of neurotransmitters. It is proposed that at a certain point, glutamate will overexcite ganglion cells to initiate a dying process. It is also hypothesised that the variability in the death rate of individual ganglion cells will depend on the degree of this overexcitement, which is dependent in part on the number of excitatory and inhibitory receptors associated with the neuron (and also upon a rise in the extracellular levels of neurotransmitters). Activation of inhibitory $G A B A$ receptors, for example, will hyperpolarise the cell and this will tend to counteract the overexcitation. 
capacity to communicate with their respective neighbouring astrocytes via gap junctions ${ }^{47} 6768$ as well as with Müller cells. ${ }^{69}$ Astrocytes therefore have the capacity to communicate with other glial cells throughout the retina. An insult in the form of reduced energy to a collection of these cells in the optic nerve head may theoretically, then, be signalled to many other retinal astrocytes. Studies on cultures of astrocytes strongly support this view. ${ }^{57}$ An oligaemic/ hypoxic insult to the optic nerve head may cause depolarisation of "local" astrocytes possibly leading to a form of spreading depression. ${ }^{70}$ Spreading depression was originally described by Leão ${ }^{71}$ as a stereotypic response of nervous tissue to a variety of noxious influences. In isolated chick retinas, the propagation of spreading depression occurs in circles with a velocity of $1-10 \mathrm{~mm} / \mathrm{min}$ and accompanying voltage changes can be detected from the ganglion cells to the photoreceptors. ${ }^{70}$ Astrocytes are thought to play a major part in the process of spreading depression in the retina with potassium, calcium, and other substances which include glutamate being involved..$^{72}$ Spreading depression is known to increase glucose consumption and to place an additional energy demand upon cells. It has also been demonstrated to occur in brain tissues during hypoxia. ${ }^{74} 75$ Thus, oligaemia/hypoxia to the optic nerve head may cause astrocytes in this region to no longer function efficiently - for example, they may become unable to maintain the correct ionic homeostasis or to communicate information to regions outside the retinal optic nerve head area. They may also release, as already mentioned, substances such as nitric oxide, ${ }^{58}$ prostaglandins ${ }^{59}$ glutamate, ${ }^{57}$ or other factors ${ }^{60}$ into the extracellular milieu, which could exacerbate injury to ganglion cells and other neighbouring structures such as microglia and the lamina cribrosa. Stressed microglia may also release a variety of substances. ${ }^{76}$ It is plausible to conclude, therefore, that an insult originating at the optic nerve head can to some degree be transmitted, over a variable period of time, to much of the retina. Moreover, substances released from stressed astrocytes and microglia, in particular in the optic nerve head region, could add to the general malaise of ganglion cells. These ideas are based mainly on studies on cultured cells as information on the intact retina is lacking.

A deficit in the supply of energy to ganglion cell axons due to oligaemia/hypoxia is likely to gradually extend in both a retrograde and an orthograde manner (see Fig 3). A variable reduction of energy (ATP) is likely therefore to exist in the ganglion cell over time with the greatest effect being in the optic nerve head region. The lamina cribrosa of the optic nerve head is likely to be at risk because of the transition between an efficient (myelinated axons) and not so efficient (unmyelinated axons) energy system of action potential transmission. This is supported by histochemical studies on the human optic nerve to strongly support the view that the unmyelinated laminar and prelaminar portions of the optic nerve have greater demands for mitochondrially derived ATP than the myelinated postlaminar segment ${ }^{77}$ and as a consequence could be more susceptible to an energy deficit. This may cause a reduced normal resting membrane potential with homeostasis of the ganglion cells now maintained at a lower status so making them more susceptible to further insults. This is similar to that which may occur in ageing. ${ }^{78}$ Since ganglion cells are laden with glutamate, it is suggested that at a lower homeostatic state there will be a tendency for some glutamate to "leak out" into the extracellular space, the rate of leakage being dependent on the energy status of the cell. Increased extracellular glutamate (originating from ganglion cells functioning at a reduced homeostasis and also possibly from astrocytes) will, over time, become toxic to neurons containing specific types of glutamate receptors

\section{Sequence specifically leading to ganglion cell death}

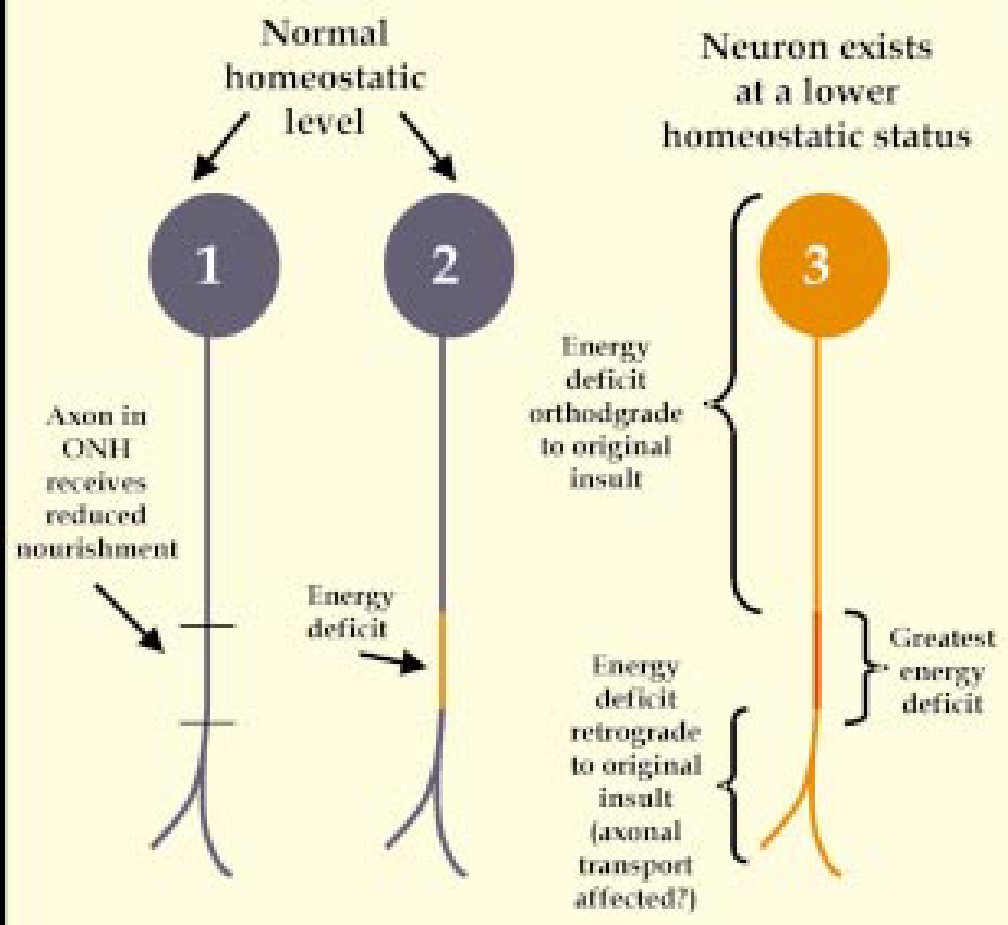

Raised extracellular levels of transmitters sufficient to trigger death to cell at lower homeostatic status
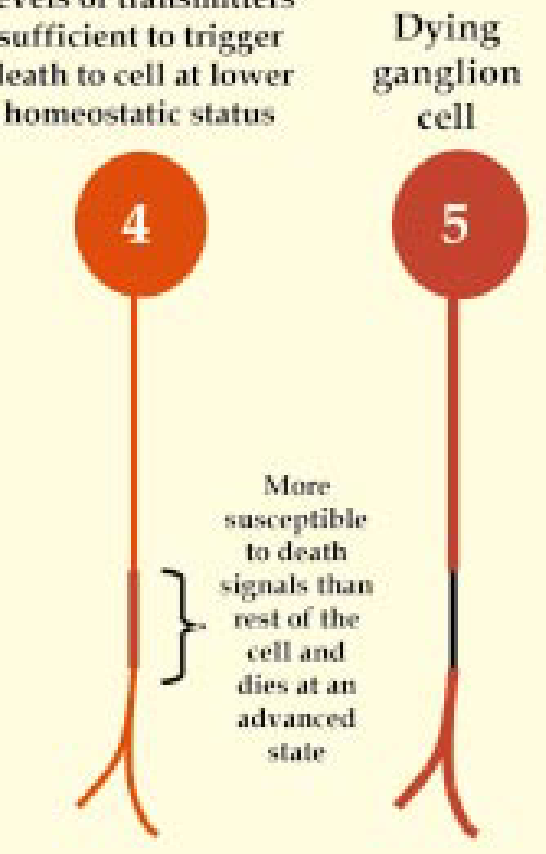
ganglion 
(ionotropic AMPA/kainate and NMDA receptors). ${ }^{6}$ The rate of take up of glutamate and subsequent metabolism and redistribution by the Müller cells will need to be increased in order to maintain non-toxic levels of glutamate in the extracellular space. ${ }^{79}{ }^{80}$ Müller cells would therefore be functioning overtime, perhaps accelerating ageing. Uptake and metabolism of glutamate are energy dependent processes and the energy demands placed on the Müller cells will be significant. It is postulated that after a time Müller cell functions will become less efficient and when this occurs the extracellular glutamate concentration will slowly rise. While a small rise may not in itself be toxic to healthy retinal neurons it may be toxic to ganglion cells already at a lower homeostatic state (see Clarke et $a l^{81}$ ). Inefficient uptake processes associated with Müller cells will eventually cause a slight rise in extracellular levels not only of glutamate but also of other neurotransmitters such as GABA. The prediction therefore is that certain Müller cell functions in glaucoma become inefficient (but not dysfunctional) with time. It is generally believed that the flash electroretinograms, and specifically the b-wave amplitude, from glaucoma patients are unaffected, which is consistent with this idea. It is worthy to note, however, that recent reports have shown a reduction of a-wave amplitude ${ }^{82}$ and a delay in b-wave implicit times ${ }^{83}$ in the dark adapted flash electroretinograms (ERGs) from patients with advanced glaucoma. Interestingly, the b-wave amplitude of the ERG is slightly reduced with ageing ${ }^{84}$ and glaucoma has been described as an "ageing disease." Inefficient function of Müller cells and subsequent elevation of extracellular neurotransmitter levels may now result in neuronal receptors being stimulated in a non-physiological manner. Also, the extracellular neurotransmitters may find a route to the vitreous humour, although one would imagine that elevated levels of glutamate in the vitreous humour would only be detectable at the most advanced stages of glaucoma. It is important to note that, in the vitreous humour of glaucoma patients, levels of the major retinal neurotransmitter glutamate ${ }^{85}$ have been reported to be elevated. ${ }^{86}$ Moreover, experimental evidence exists to show that Müller cells are affected in a monkey glaucoma model. ${ }^{87} 88$

It has been postulated that a small rise in extracellular glutamate will cause overstimulation of ionotropic glutamate receptors ${ }^{89}$ which are expressed throughout the retina..$^{90}$ It is conceivable that certain ganglion cells will be particularly susceptible to this neurotoxic phenomenon because they are at a lower homeostatic state compared with other neurons because of oligaemic/hypoxic insults to their axons in the optic nerve head region. Stimulation of glutamate receptors leads to depolarisation and uncontrolled or excessive depolarisation may cause cell death. ${ }^{89} \mathrm{~A}$ small but maintained rise in the extracellular levels of the two major retinal neurotransmitters, glutamate and GABA, could provide a simple explanation for the variation in ganglion cell death timing. ${ }^{43}$ The repertoire of receptors associated with ganglion cells is known to vary. These cells express glutamate and GABA receptors. Activation of two of the three types of GABA receptor in ganglion cells $\left(\mathrm{GABA}_{\mathrm{A}}\right.$ and $\left.\mathrm{GABA}_{\mathrm{B}}\right)$ causes hyperpolarisation $^{91}{ }^{92}$ while activation of ionotropic glutamate receptors (NMDA, kainate, and AMPA) leads to depolarisation. ${ }^{93}$ Excessive or uncontrolled depolarisation of neurons leads to cell death and this is triggered by an initial influx of sodium and calcium ions. ${ }^{63}$ Furthermore, the degree of depolarisation of any single ganglion cell will depend upon the numbers and types of GABA and glutamate receptors associated with that cell. We suggest, therefore, that a ganglion cell expressing a defined number of excitatory (for example, glutamate) receptors will theoretically be more susceptible than a similar cell expressing the same excitatory receptors plus some inhibitory (for example, GABA) receptors. ${ }^{43}$ Inhibitory and excitatory receptors associated with ganglion cells are not exclusively GABAergic and glutamatergic, respectively. Inhibitory receptors include those responsive to adenosine ( $\mathrm{A}_{1}$ type), serotonin (5- $\mathrm{HT}_{1 \mathrm{~A}}$ type), and noradrenaline ( $\alpha_{2}$ adrenergic type) while excitatory receptors include the nicotinic acetylcholine type. There is reasonable evidence to suggest that ganglion cells contain nicotinic, ${ }^{94}$ adenosine, ${ }^{95}$ and $\alpha_{2}$ adrenergic $^{96}$ receptors.

It is important to emphasise that this theory suggests that initial insults to all or most of the ganglion cells in glaucoma occur on their axons in the optic disc head region and that the rate of individual ganglion cell death would be further determined by the receptor profile associated with the ganglion cell body and dendrites (Fig 3). Thus the axon (in the optic nerve head region in particular) of a dying ganglion cell in glaucoma is predicted to be at a more advanced stage in the death process than the cell body. This may be compared with a dying ganglion cell in retinal ischaemia (for example, central retinal artery occlusion) where deterioration of the ganglion cell body is at a more advanced state than within the axon. It is also suggested that the cascade of events that leads to ganglion cell death in glaucoma as proposed proceeds at a very slow and variable rate depending on the nature of the oligaemic/ hypoxic insult to the optic nerve head. The insult may either be gradual, continuous, or variable in intensity and may occur over many years.

\section{Putative ways for reducing the rate of ganglion cell death}

A number of putative therapeutic strategies are summarised in Table 1. Stopping whatever risk factor(s) cause(s) the oligaemic/hypoxic-like insult in the optic nerve head would be hypothesised to be an ideal way to attenuate ganglion cell death. If instances were found where raised IOP was identified as the major cause of the insult, then reducing IOP either by surgery or with a pharmacological agent would be the ideal approach (see Osborne et $a l^{6}$ ). Lowering IOP, nevertheless, often proves beneficial even in patients with normal tension glaucoma, ${ }^{97}{ }^{98}$ suggesting that there is a level of "tolerable" IOP which depends on other accompanying factors, such as the quality of blood supply to the optic nerve head. In such cases, one approach might be to correct whatever causes the change in the quality of blood supply in the microvasculature of the optic nerve head. This could mean simply increasing blood flow in the optic nerve head, assuming such a strategy is feasible. Until it is possible to establish reasons for any alterations in the quality of the blood supply in the optic nerve head, it will be difficult to devise an appropriate treatment. The term vasoprotection has been coined in this connection. ${ }^{99}$

The term neuroprotection, in the context of glaucoma, implies that an agent reaches the retina and slows down the cascade of events leading to ganglion cell death. ${ }^{63} \mathrm{~A}$ number of substances have been shown to attenuate ganglion cell death in animal experiments. These include certain neurotrophins, NMDA receptor antagonists, free

Table 1 Summary of possible pharmacological ways to attenuate ganglion cell destruction as suggested in Figures 2 and 3

- Counteract risk factor in question - eg, lower raised IOP

- Maintain normal blood supply to optic nerve head

- Prevent hypoxic/oligaemic insult to ganglion cell axons

- Prevent substance release from astrocytes/microglia that may affect ganglion cell survival

- Maintain optimum functioning of Müller cells

- Prevent glutamate toxicity to retinal neurons

- Prevent excessive depolarisation of ganglion cells

- Administration of neurotrophic factors 
radical scavengers, calcium channel blockers, $\alpha$ adrenoceptor agonists, betaxolol, and nitric oxide synthase inhibitors. ${ }^{100}$ Neurotrophins, for example, protect ganglion cells because their endogenous supply is partially or completely reduced by a disruption of the retrograde transport process associated with ganglion cell axons. ${ }^{101}$ It remains to be investigated whether a drug that stops spreading depression will benefit glaucoma patients. It is known that some compounds (such as MK-801) are able to inhibit retinal spreading depression associated with astrocytes ${ }^{70}$ and can also protect against ischaemia induced damage. ${ }^{102-104}$

Pharmacological agents which counteract changes to optic nerve head astrocytes caused by an oligaemic/ hypoxic insult may also benefit glaucoma patients. Support for this idea comes from the work of Neufeld and collaborators. ${ }^{5}$ They have showed that nitric oxide synthase is altered in optic nerve head astrocytes in both glaucoma patients and also in animals following a sustained elevation of IOP. Moreover, treatment of animals with a nitric oxide synthase inhibitor attenuated the ganglion cell death induced by sustained elevated IOP. ${ }^{5}$ Excessive production of nitric oxide by "reactive" astrocytes in the optic nerve head has been proposed to have a major role in axonal degeneration. ${ }^{58}$

To attenuate ganglion cell death in glaucoma patients it is necessary to have agents that particularly protect the axon and, secondly, the cell body. Studies on isolated optic nerves have shown that voltage sensitive sodium channel blockers ${ }^{105} 106$ and drugs which prevent the reversal of the sodium/calcium exchanger ${ }^{106} 107$ attenuate anoxia induced death of ganglion cell axons. In this respect, it is of interest to note that a number of $\beta$ adrenoceptor antagonists currently used to lower IOP in glaucoma patients can reduce certain cation influx into neurons by directly interacting with specific sodium or calcium voltage gated channels. ${ }^{108} 109$ There is no evidence that any of the other antiglaucoma drugs behave similarly. Of the $\beta$ blockers tested, betaxolol displays the most potent sodium and calcium blocking activity and these properties may be related to its ability to partially counteract ganglion cell death in rats and rabbits induced by raised IOP. ${ }^{110}{ }^{111}$ Agents which reduce excessive depolarisation occurring subsequent to proposed Müller cell inefficiency may also be used to protect overall ganglion cell function. Substances that may be of use include excitatory receptor antagonists, inhibitory receptor agonists ( $\alpha_{2}$ adrenoceptor agonists), and voltage sensitive sodium or calcium channel blockers. Support for this view comes from experimental studies where glutamate receptor antagonists such as $\mathrm{MK}-801,{ }^{102}$ memantine $^{112}$ and dextromethorphan, ${ }^{113} 114$ inhibitory receptor agonists such as R-PIA (adenosine $\mathrm{A}_{1}$ receptor agonist), ${ }^{115}$ brimonidine, ${ }^{116}$ and clonidine, ${ }^{117}$ and voltage sensitive calcium channel blockers ${ }^{118} 119$ all reduce retinal damage induced by raised IOP.

Attenuation of ganglion cell death can theoretically, therefore, be implemented by slowing down the biochemical events that follow depolarisation/excitotoxicity induced insults. ${ }^{63}$ This would also be achieved by using free radical scavengers, for example. Numerous laboratory studies have showed that ischaemia induced destruction of animal ganglion cells can be attenuated in this manner. ${ }^{12-123}$ In glaucoma, however, it should be borne in mind that the ganglion cell axon is proposed to be at a more compromised state than the rest of the ganglion cell while in ischaemia, for example, this is not the case. Agents, therefore, that are targeted to protect the ganglion cell generally by preventing excessive depolarisation (for example, NMDA antagonists, GABA agonists) without paying particular attention to the axon may not be the ideal drugs for use in glaucoma.
Yet another theoretical approach to attenuating ganglion cell death in glaucoma would be to maintain the optimum health and functioning of Müller cells for as long as possible after the hypothesised initial insult in the optic nerve head. Evidence from the basic sciences suggests that altered Müller cell function exacerbates ganglion cell death $^{124}$ so this approach is worthy of pursuit. Agents that stimulate glycogenolysis or glutamate transport and metabolism in the Müller cells may prove beneficial in this respect.

\section{Conclusions}

Despite the quantities written about glaucoma, definitive data on the subject are sparse. The disease(s) is/are characterised by a defined optic neuropathy with a progressive loss of vision that is of a specific pattern. We hypothesise, therefore, that ganglion cell axon injury caused by oligaemic/hypoxic insults to components in the optic nerve head could ultimately lead to an insult at the level of the ganglion cell body and dendrites owing to inefficient Müller cell function. We also hypothesise that Müller cells and astrocytes play an important part in this whole process with the latter cell type particularly contributing to the cupping associated with glaucoma. For a substance to effectively protect the ganglion cell in glaucoma it should have an action on the ganglion cell axon and, secondly, the rest of the cell. However, such a substance may not be effective enough to have a measurable neuroprotective effect for glaucoma patients unless some of the other proposed processes contributing to ganglion cell death are blunted (Fig 2). It is therefore suggested that the way forward to treat glaucoma would be to use a cocktail of substances, which when administered would reach the retina, and in doing so protects not only the ganglion cells, particularly their axons, but also, for example, maintain optimum functioning of the Müller cells, and counteract any negative physiological and pharmacological effects from the astrocytes and/or microglial cells.

The present article is an attempt to provide an explanation as to how ganglion cells may be initiated to die in glaucoma, so as to develop therapeutic strategies for the treatment of the disease. It is not meant to contradict ideas put forward by other authors but more to serve for debate and stimulate future research. Definitive data about ganglion cell death in glaucoma are sparse and consequently many of the ideas for the proposed theory are derived from general studies on nervous systems. We nevertheless feel that the hypothesised approach has merit even though caution is necessary. We are of the opinion that the slow progression of glaucoma does provide scientists and clinicians with the real possibility of slowing down the rate of ganglion cell death and to develop a pharmacological means of doing so warrants a working hypothesis. For this idea to become feasible, it will also probably be necessary to develop procedures to enable delivery of the "neuroprotectant" to the retina. There is a need to remain optimistic despite the lack of success in finding similar ways to slow down the rate of neuronal death in other diseases of the central nervous system. The implication from the theory proposed is to suggest that pharmacological agents that act solely at the ganglion cell level (Fig 3) may not be sufficient for effective neuroprotection in glaucoma and that only by blunting several of the other negative processes involved in the disease (Figs 1 and 2) will real progress be made. We would like to thank Mr JF Salmon, FRCS (Oxford), Dr Robert Casson, and
Professor Josef Flammer (Basle) for helpful suggestions. NNO is also indebted to Professor SS Hayreh (Iowa City) for the scholarly information he provided. We also wish to thank the Royal National Institute for the Blind (JPMW) and the EU (JM) for financial support. GC is supported by the Olga Knoop Fellowthe EU
ship. 


\section{NEVILLE N OSBORNE} JOSÉ MELENA

GLYN CHIDLOW JOHN P M WOOD

Nuffield Laboratory of Ophthalmology, University of Oxford, Walton Street, Oxford OX2 6AW, UK

Correspondence to: Professor Neville N Osborne

1 Gupta N, Weinreb RN. New definitions of glaucoma. (Review) Curr Opin Ophthalmol 1997;8:38-41

2 Quigley HA. Neuronal death in glaucoma. Prog Retin Eye Res 1999;18:3957.

3 Shareef SR, Garcia Valenzuela E, Salierno A, et al. Chronic ocular hypertension following episcleral venous occlusion in rats. Exp Eye Res 1995;61:379-82.

4 Morrison JC, Moore CG, Deppmeier LM, et al. A rat model of chronic pressure-induced optic nerve damage. Exp Eye Res 1997;64:85-96.

5 Neufeld AH, Sawada A, Becker B. Inhibition of nitric-oxide synthase 2 by aminoguanidine provides neuroprotection of retinal ganglion cells in a rat
model of chronic glaucoma. Proc Natl Acad Sci USA 1999;96:9944-8.

6 Osborne NN, Ugarte M, Chao M, et al. Neuroprotection in relation to retiOsborne NN, Ugarte M, Chao M, et al. Neuroprotection in relation to reti-
nal ischemia and relevance to glaucoma. Surv Ophthalmol 1999;43(Supp1 nal ischemia

7 Laquis S, Chaudhary P, Sharma SC. The patterns of retinal ganglion cell death in hypertensive eyes. Brain Res 1998;784:100-4.

8 Johnson EC, Deppmeier LM, Wentzien SK, et al. Chronology of optic nerve head and retinal responses to elevated intraocular pressure. Invest Ophthalmol Vis Sci 2000;41:431-42.

9 Garcia Valenzuela E, Shareef S, Walsh J, et al. Programmed cell death of retinal ganglion cells during experimental glaucoma. Exp Eye Res 1995;61: 33-44.

10 Nickells RW. Retinal ganglion cell death in glaucoma: the how, the why, and the maybe. F Glaucoma 1996;5:345-56.

11 Morgan JE. Optic nerve head structure in glaucoma: astrocytes as mediators of axonal damage. Eye 2000;14:437-44.

12 Hayreh SS. The role of age and cardiovascular disease in glaucomatous optic neuropathy. Surv Ophthalmol 1999;43 (Suppl) 1:S27-42.

13 Bechetoille A. Vascular risk factors in glaucoma. Curr Opin Ophthalmol 1996;7:39-43.

14 Sommer A. Glaucoma risk factors observed in the Baltimore Eye Survey. Curr Opin Ophthalmol 1996;7:93-8.

15 Prünte C, Orgul S, Flammer J. Abnormalities of microcirculation in glaucoma: facts and hints. Curr Opin Ophthalmol 1998;9:50-5.

16 Bonomi L, Marchini G, Marraffa M, et al. Vascular risk factors for primary open angle glaucoma: the Egna-Neumarkt Study. Ophthalmology 2000;107: 1287-93.

17 Douglas GR. Pathogenetic mechanisms of glaucoma not related to intraocular pressure. Curr Opin Ophthalmol 1998;9:34-8.

18 Klein BE, Klein R, Sponsel WE, et al. Prevalence of glaucoma. The Beaver Dam Eye Study. Ophthalmology 1992;99:1499-504

19 Tielsch JM, Katz J, Singh K, et al. A population-based evaluation of glaucoma screening: the Baltimore Eye Survey. Am f Epidemiol 1991;134: 1102-10.

20 Sommer A. Intraocular pressure and glaucoma. Am f Ophthalmol 1989;107: $186-8$.

21 Hitchings RA. Chronic glaucoma: definition of the phenotype. Eye 2000;14: 419-21.

22 Flammer J, Orgul S. Optic nerve blood-flow abnormalities in glaucoma. Prog Retin Eye Res 1998;17:267-89.

23 Grunwald JE, Piltz J, Hariprasad SM, et al. Optic nerve and choroidal circulation in glaucoma. Invest Ophthalmol Vis Sci 1998;39:2329-36.

24 Kerr J, Nelson P, O'Brien C. A comparison of ocular blood flow in untreated primary open-angle glaucoma and ocular hypertension. Am f Ophthalmol 1998;126:42-51.

25 Yamamoto T, Kitazawa Y. Vascular pathogenesis of normal-tension glaucoma: a possible pathogenetic factor, other than intraocular pressure, of glaucomatous optic neuropathy. Prog Retin Eye Res 1998;17:127-43.

26 Hayreh SS, Blood supply of the optic nerve head: A "reality check". In Pillunat LE, Harris A, Anderson DR, et al, eds. Current concepts in ocular blood flow in glaucoma. The Hague: Kugler Publications, 1999:3-31.

27 Park KH, Tomita G, Liou SY, et al. Correlation between peripapillary atrophy and optic nerve damage in normal-tension glaucoma. Ophthalmology 1996;103:1899-906.

28 Yamazaki S, Inoue Y, Yoshikawa K. Peripapillary fluorescein angiographic findings in primary open angle glaucoma. Br F Ophthalmol 1996;80:812-7.

29 Chung HS, Harris A, Kagemann L, et al. Peripapillary retinal blood flow in normal tension glaucoma. Br f Ophthalmol 1999;83:466-9.

30 Hayreh SS, Podhajsky P, Zimmerman MB. Role of nocturnal arterial hypotension in optic nerve head ischemic disorders. Ophthalmologica 1999;213: 76-96.

31 Hayreh SS. Factors influencing blood flow in the optic nerve head. F Glaucoma 1997;6:412-25.

32 Hayreh SS. Inter-individual variation in blood supply of the optic nerve head. Its importance in various ischemic disorders of the optic nerve head, and glaucoma, low-tension glaucoma and allied disorders. Doc Ophthalmol 1985;59:217-46.

33 Geijer C, Bill A. Effects of raised intraocular pressure on retinal, prelaminar, aminar, and retrolaminar optic nerve blood flow in monkeys. Invest Ophthalmol Vis Sci 1979;18:1030-42.

34 Kiel JW, van Heuven WA. Ocular perfusion pressure and choroidal blood flow in the rabbit. Invest Ophthalmol Vis Sci 1995;36:579-85.

35 Anderson DR. Introductory comments on blood flow autoregulation in the optic nerve head and vascular risk factors in glaucoma. Surv Ophthalmol 1999;43(Suppl 1):S5-9.

36 Orgul S, Gugleta K, Flammer J. Physiology of perfusion as it relates to the optic nerve head. Surv Ophthalmol 1999;43(Suppl 1):S17-26.

37 Evans DW, Harris A, Garrett M, et al. Glaucoma patients demonstrate faulty autoregulation of ocular blood flow during posture change. Br f Ophthalmol 1999;83:809-13.

38 Broadway DC, Drance SM. Glaucoma and vasospasm. Br f Ophthalmol 1998;82:862-70.
39 Caprioli J, Sears M, Miller JM. Patterns of early visual field loss in open-angle glaucoma. Am f Ophthalmol 1987;103:512-7.

40 Hart WM Jr, Becker B. The onset and evolution of glaucomatous visual field defects. Ophthalmology 1982;89:268-79.

41 Jonas JB, Fernandez MC, Sturmer J. Pattern of glaucomatous neuroretinal rim loss. Ophthalmology 1993;100:63-8.

42 Glovinsky Y, Quigley HA, Dunkelberger GR. Retinal ganglion cell loss is size dependent in experimental glaucoma. Invest Ophthalmol Vis Sci 1991; 32:484-91

43 Osborne NN, Wood JP, Chidlow G, et al. Ganglion cell death in glaucoma: what do we really know? Br f Ophthalmol 1999;83:980-6.

44 Hernandez MR, Pena JD. The optic nerve head in glaucomatous optic neuropathy. Arch Ophthalmol 1997;115:389-95.

45 Pena JD, Netland PA, Vidal I, et al. Elastosis of the lamina cribrosa in glaucomatous optic neuropathy. Exp Eye Res 1998;67:517-24.

46 Neufeld AH. Microglia in the optic nerve head and the region of parapapillary chorioretinal atrophy in glaucoma. Arch Ophthalmol 1999;117:1050-6.

47 Hernandez MR. The optic nerve head in glaucoma: role of astrocytes in tissue remodeling. Prog Retin Eye Res 2000;19:297-321.

48 Sommer A, Katz J, Quigley HA, et al. Clinically detectable nerve fiber atrophy precedes the onset of glaucomatous field loss. Arch Ophthalmol

49 Quigley HA, Katz J, Derick RJ, et al. An evaluation of optic disc and nerve fiber layer examinations in monitoring progression of early glaucoma damage. Ophthalmology 1992;99:19-28.

50 Pederson JE, Anderson DR. The mode of progressive disc cupping in ocular hypertension and glaucoma. Arch Ophthalmol 1980;98:490-5.

51 Sommer A, Miller NR, Pollack I, et al. The nerve fiber layer in the diagnosis of glaucoma. Arch Ophthalmol 1977;95:2149-56.

52 Sommer A, Pollack I, Maumenee AE. Optic disc parameters and onset of glaucomatous field loss. I. Methods and progressive changes in disc morphology. Arch Ophthalmol 1979;97:1444-8.

53 Petty MA, Wettstein JG. White matter ischaemia. Brain Res Brain Res Rev 1999;31:58-64.

54 Swanson RA, Farrell K, Stein BA. Astrocyte energetics, function, and death under conditions of incomplete ischemia: a mechanism of glial death in the penumbra. Glia 1997;21:142-53.

55 Yan X, Tezel G, Wax MB, et al. Matrix metalloproteinases and tumor necrosis factor alpha in glaucomatous optic nerve head. Arch Ophthalmol 2000;118:666-73.

56 Tezel G, Wax MB. Increased production of tumor necrosis factor- $\alpha$ by glial cells exposed to simulated ischemia or elevated hydrostatic pressure induces apoptosis in cocultured retinal ganglion cells. $f$ Neurosci 2001;20:8693-700

57 Innocenti B, Parpura V, Haydon PG. Imaging extracellular waves of glutamate during calcium signaling in cultured astrocytes. F Neurosci 2000; 20:1800-8.

58 Liu B, Neufeld AH. Expression of nitric oxide synthase-2 (NOS-2) in reactive astrocytes of the human glaucomatous optic nerve head. Glia 2000;30: $178-86$.

59 Miettinen S, Fusco FR, Yrjanheikki J, et al. Spreading depression and focal brain ischemia induce cyclooxygenase- 2 in cortical neurons through N-methyl-D-aspartic acid-receptors and phospholipase A2. Proc Natl Acad Sci USA 1997;94:6500-5.

60 Ridet JL, Malhotra SK, Privat A, et al. Reactive astrocytes: cellular and molecular cues to biological function. Trends Neurosci 1997;20:570-7.

61 Baranano DE, Ferris CD, Snyder SH. Atypical neural messengers. Trends Neurosci 2001;24:99-106

62 Bianchi Marzoli S, Rizzo JF 3rd, Brancato R, et al. Quantitative analysis of optic disc cupping in compressive optic neuropathy. Ophthalmology 1995;102:436-40.

63 Danesh-Meyer HV, Savino PJ, Sergott RC. The prevalence of cupping in end-stage arteritic and nonarteritic anterior ischemic optic neuropathy. Ophthalmology 2001;108:593-8.

64 Orgul S, Gass A, Flammer J. Optic disc cupping in arteritic anterior ischemic optic neuropathy. Ophthalmologica 1994;208:336-8.

65 Ortiz RG, Newman NJ, Manoukian SV, et al. Optic disk cupping and electrocardiographic abnormalities in an American pedigree with Leber's hereditary optic neuropathy. Am f Ophthalmol 1992;113:561-6.

66 Hayreh SS. Pathogenesis of cupping of the optic disc. Brf Ophthalmol 1974; 58:863-76.

67 Yu ACH, Hertz L, Norenberg MD, et al. Neuronal-astrocytic interactions: implications for normal and pathological CNS function. Amsterdam: Elsevier, 1992

68 Nedergaard M. Spreading depression as a contributor to ischemic brain damage. Adv Neurol 1996;71:75-83; discussion 84.

69 Newman EA. Propagation of intercellular calcium waves in retinal astrocytes and Muller cells. $\mathcal{F}$ Neurosci 2001;21:2215-23.

70 Martins Ferreira H, Nedergaard M, Nicholson C. Perspectives on spreading depression. Brain Res Brain Res Rev 2000;32:215-34.

71 Leão AAP. Spreading depression of activity in the cerebral cortex. $\mathcal{F}$ Neurophysiol 1944;7:359-90.

72 Sheardown MJ. The triggering of spreading depression in the chicken retina: a pharmacological study. Brain Res 1993;607:189-94.

73 Van Harreveld A. Two mechanisms for spreading depression in the chicken retina. F Neurobiol 1978;9:419-31.

74 Obeidat AS, Andrew RD. Spreading depression determines acute cellular damage in the hippocampal slice during oxygen/glucose deprivation. Eur $\mathcal{F}$ Neurosci 1998:10:3451-61.

75 Kocher M. Metabolic and hemodynamic activation of postischemic rat brain by cortical spreading depression. F Cereb Blood Flow Metab 1990;10: $564-71$

76 Streit WJ, Walter SA, Pennell NA. Reactive microgliosis. Prog Neurobiol 1999;57:563-81.

77 Andrews RM, Griffiths PG, Johnson MA, et al. Histochemical localisation of mitochondrial enzyme activity in human optic nerve and retina. $\mathrm{Br} f \mathrm{Oph}$ thalmol 1999;83:231-5.

78 Semsei I. On the nature of aging. Mech Ageing Dev 2000;117:93-108.

79 Newman E, Reichenbach A. The Muller cell: a functional element of the retina. Trends Neurosci 1996;19:307-12.

80 Kalloniatis M, Tomisich G. Amino acid neurochemistry of the vertebrate retina. Prog Retin Eye Res 1999;18:811-66.

81 Clarke G, Collins RA, Leavitt BR, et al. A one-hit model of cell death in inherited neuronal degenerations. Nature 2000;406:195-9. 
82 Velten IM, Korth M, Horn FK. The a-wave of the dark adapted electroretinogram in glaucomas: are photoreceptors affected? Br F Ophthalelectroretinogram in gla
mol 2001;85:397-402.

83 Velten IM, Horn FK, Korth M, et al. The b-wave of the dark adapted flash electroretinogram in patients with advanced asymmetrical glaucoma and normal subjects. Br f Ophthalmol 2001;85:403-9.

84 Weleber RG. The effect of age on human cone and rod ganzfeld electroretinograms. Invest Ophthalmol Vis Sci 1981;20:392-9.

85 Massey SC. Cell types using glutamate as a neurotransmitter in the vertebrate retina. Prog Ret Eye Res 1990;9:399-425.

86 Dreyer EB, Zurakowski D, Schumer RA, et al. Elevated glutamate levels in the vitreous body of humans and monkeys with glaucoma. Arch Ophthalmol 1996;114:299-305.

87 Carter Dawson L, Shen F, Harwerth RS, et al. Glutamine immunoreactivity in Muller cells of monkey eyes with experimental glaucoma. Exp Eye Res 1998;66:537-45.

88 Tanihara $\mathrm{H}$, Hangai $\mathrm{M}$, Sawaguchi S, et al. Up-regulation of glial fibrillary acidic protein in the retina of primate eyes with experimental glaucoma. Arch Ophthalmol 1997;115:752-6.

89 Siesjo BK. Pathophysiology and treatment of focal cerebral ischemia. Part I: Pathophysiology. I Neurosurg 1992;77:169-84.

90 Thoreson WB, Witkovsky P. Glutamate receptors and circuits in the vertebrate retina. Prog Retin Eye Res 1999;18:765-810

91 Muller F, Boos R, Wassle H. Actions of GABAergic ligands on brisk ganglion cells in the cat retina. Vis Neurosci 1992;9:415-25.

92 Ishida AT, Cohen BN. GABA-activated whole-cell currents in isolated retinal ganglion cells. $\mathcal{F}$ Neurophysiol 1988;60:381-96.

93 Velte TJ, Yu W, Miller RF. Estimating the contributions of NMDA and nonNMDA currents to EPSPs in retinal ganglion cells. Vis Neurosci 1997;14:999-1014.

94 Baldridge WH. Optical recordings of the effects of cholinergic ligands on neurons in the ganglion cell layer of mammalian retina. I Neurosci 1996;16: 5060-72.

95 Braas KM, Zarbin MA, Snyder SH. Endogenous adenosine and adenosine receptors localized to ganglion cells of the retina. Proc Natl Acad Sci USA 1987;84:3906-10.

96 WoldeMussie E, Wijono $\mathrm{M}$, Bogardus A, et al. Determination of the presence of alpha 2 adrenergic receptor subtypes in the rat retina. Invest presence of alpha 2 adrenergic rece
Ophthalmol Vis Sci 1999;40:S673.

97 Group CN-TGS. The effectiveness of intraocular pressure reduction in the treatment of normal-tension glaucoma. Am ₹ Ophthalmol 1998;126:498treatm.

98 Group CN-TGS. Comparison of glaucomatous progression between untreated patients with normal-tension glaucoma and patients with therapeutically reduced intraocular pressures. Am f Ophthalmol 1998;126:48797

99 Harris A, Ciulla TA, Kagemann L, et al. Vasoprotection as neuroprotection for the optic nerve. Eye 2000;14:473-5.

100 Osborne NN, Chidlow G, Wood JPM. Expectations in the treatment of retinal diseases: neuroprotection. Curr Eye Res 2001; (in press)

101 Quigley HA, McKinnon SJ, Zack DJ, et al. Retrograde axonal transport of BDNF in retinal ganglion cells is blocked by acute IOP elevation in rats. Invest Ophthalmol Vis Sci 2000;41:3460-6.

102 Lam TT, Siew E, Chu R, et al. Ameliorative effect of MK-801 on retinal ischemia. F Ocul Pharmacol Ther 1997;13:129-37.

103 Joo CK, Choi JS, Ko HW, et al. Necrosis and apoptosis after retinal ischemia: involvement of NMDA-mediated excitotoxicity and p53. Invest ischemia: involvement of NMDA-m

104 Adachi K, Kashii S, Masai H, et al. Mechanism of the pathogenesis of glutamate neurotoxicity in retinal ischemia. Graefes Arch Clin Exp Ophthalmol 1998;236:766-74.
105 Waxman SG, Black JA, Ransom BR, et al. Anoxic injury of rat optic nerve: ultrastructural evidence for coupling between $\mathrm{Na}^{+}$influx and $\mathrm{Ca}^{2+}$ mediated injury in myelinated CNS axons. Brain Res 1994;644:197-204.

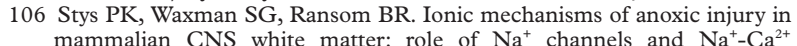
mammalian CNS white matter.

107 Stys PK. Ions, channels, and transporters involved in anoxic injury of central nervous system white matter. Adv Neurol 1996;71:153-63; discussion 63-6.

108 Chidlow G, Melena J, Osborne NN. Betaxolol, a $\beta_{1}$-adrenoceptor antagonist, reduces $\mathrm{Na}^{+}$influx into cortical synaptosomes by direct interaction with $\mathrm{Na}^{+}$channels: comparison with other $\beta$-adrenoceptor antagonists. $\mathrm{Br}$ f Pharmacol 2000;130:759-66.

109 Melena J, Wood JP, Osborne NN. Betaxolol, a $\beta_{1}$-adrenoceptor antagonist, has an affinity for L-type $\mathrm{Ca}^{2+}$ channels. Eur f Pharmacol 1999;378:317-22.

110 Osborne NN, DeSantis L, Bae JH, et al. Topically applied betaxolol attenuates NMDA-induced toxicity to ganglion cells and the effects of ischaemia to the retina. Exp Eye Res 1999;69:331-42.

111 Wood JPM, DeSantis L, Chao H-M, et al. Topically applied betaxolol attenuates ischaemia-induced effects to the rat retina and stimulates BDNF mRNA. Exp Eye Res 2001;72:79-86.

112 Osborne NN. Memantine reduces alterations to the mammalian retina, in situ, induced by ischemia. Vis Neurosci 1999;16:45-52.

113 Cao W, Zaharia M, Drumheller A, et al. Effects of dextromethorphan on ischemia induced electroretinogram changes in rabbit. Curr Eye Res 1994; 13:97-102.

114 Gupta LY, Marmor MF. Mannitol, dextromethorphan, and catalase minimize ischemic damage to retinal pigment epithelium and retina. Arch Ophthalmol 1993;111:384-8.

115 Larsen AK, Osborne NN. Involvement of adenosine in retinal ischemia. Studies on the rat. Invest Ophthalmol Vis Sci 1996;37:2603-11.

116 Yoles E, Wheeler LA, Schwartz M. Alpha2-adrenoreceptor agonists are neuroprotective in a rat model of optic nerve degeneration. Invest Ophthalmol Vis Sci 1999;40:65-73.

117 Chao H-M, Chidlow G, Melena J, et al. An investigation into the potential mechanisms underlying the neuroprotective effect of clonidine in the retina. Brain Res 2000;877:47-57.

118 Crosson CE, Willis JA, Potter DE. Effect of the calcium antagonist, nifedipine, on ischemic retinal dysfunction. F Ocul Pharmacol 1990;6:293-9.

119 Toriu N, Akaike A, Yasuyoshi H, et al. Lomerizine, a $\mathrm{Ca}^{2+}$ channel blocker, reduces glutamate-induced neurotoxicity and ischemia/reperfusion damage in rat retina. Exp Eye Res 2000;70:475-84.

120 Peachey NS, Green DJ, Ripps H. Ocular ischemia and the effects of allopurinol on functional recovery in the retina of the arterially perfused cat eye. Invest Ophthalmol Vis Sci 1993;34:58-65.

121 Gehlbach P, Purple RL. Enhancement of retinal recovery by conjugated deferoxamine after ischemia-reperfusion. Invest Ophthalmol Vis Sci 1994;35:669-76.

122 Ophir A, Berenshtein E, Kitrossky N, et al. Protection of the transiently ischemic cat retina by zinc-desferrioxamine. Invest Ophthalmol Vis Sci 1994;35:1212-22.

123 Banin E, Berenshtein E, Kitrossky N, et al. Gallium-desferrioxamine protects the cat retina against injury after ischemia and reperfusion. Free Radic Biol Med 2000;28:315-23.

124 Wang X, Tay SS, Ng YK. An immunohistochemical study of neuronal and glial cell interactions in retinae of rats with experimental glaucoma. Exp Brain Res 2000;132:476-84. 